Павлунько М. Я., канд. військ. наук

$(0000-0001-8255-6245)$

Посмітюх О. І., канд. військ. наук, доцент

Сергієнко В. Д., канд. техн. наук, доцент

Богатов О. I., канд. техн. наук, доцент

Інститут забезпечення військ (сил) та інформаційних технологій Національного університету оборони України імені Івана Черняховського, Київ

\title{
Аналіз бойового застосування збройних сил Російської Федерації під час стратегічних командно-штабних навчань серії "Захід"
}

Резюме. У статті розглянуто стратегічні командно-штабні навчання серії “Захід”, які є головним елементом воєнно-політичної діяльності Союзної держави Білорусі та Російської Федерації у воєннополітичній сфері, а також підсумковим етапом бойової підготовки Регіонального угруповання військ їх збройних сил. Проведено аналіз форм і способів застосування видів і родів військ збройних сил Російської Федерації.

Ключові слова: військові навчання; військові операції; оперативна та бойова підготовка; “холодна війна"; прогноз; безпека.

Постановка проблеми. Проведення масштабних військових операцій $є$ одним 3 основних інструментів з реалізації зовнішньої політики Російської Федерації (РФ). Воєнна доктрина РФ, яка була прийнята в грудні 2014 року та доопрацьована на основі положень нової Стратегії національної безпеки РФ від 2015 року, а також у проєкті нової Воєнної доктрини, презентованої 2 березня 2019 року на засіданні Академії військових наук у Москві начальником генштабу збройних сил (3C) Російської Федерації, трактуються основні завдання ЗС РФ. Під час проведення стратегічних командно-штабних навчань були апробовані форми i способи застосування видів і родів ЗС РФ у розрізі виконання основних завдань нових доктринальних документів, що потребує аналізу і вивчення.

Аналіз останніх досліджень i публікацій. На теперішній час у Воєнній доктрині РФ 2014 року [1] та положеннях нової Стратегії національної безпеки РФ [2] від 2015 року визначаються основні завдання ЗС РФ, вирішення яких відпрацьовуються під час стратегічного командно-штабного навчання (СКШН) серії “Захід”. СКШН є головним елементом воєнно-політичної діяльності РФ у воєнно-політичній сфері та підсумковим етапом бойової підготовки Регіонального угруповання військ їх збройних сил. Можливості щодо використання ЗС РФ в різного роду масштабних військових операцій проти іiі противників розглянуто у публікаціях, а саме у:
[3] проаналізовані завдання бойового застосування ЗС РФ на основних стратегічних (операційних) напрямках;

[4] відмічено, що вперше під час проведення СКШН серії “Захід-1999” були задіяні МВС, МНС та інші силові структури оперативно підпорядковані одній особі, одному відомству i діяли під одним керівництвом;

[5] висвітлено основне завдання СКШН - безпосередня підготовка збройних сил РФ і Білорусі до забезпечення стратегічної стабільності в Східноєвропейському регіоні та надані президентом РФ першочергові завдання щодо розбудови ЗС РФ;

[6] оцінено оперативну сумісність збройних сил РФ та Білорусі;

[7] перевірено злагодженість дій всіх органів військового управління, всіх підрозділів - від окремого взводу до армії, оперативна сумісність штабів різних рівнів, а також перспективних систем управління військами та зброєю.

Під час СКШН серії “Захід” РФ демонструє силу перед США і НАТО в Європі та відпрацьовує сценарій підготовки до широкомасштабної війни 3 ними на Європейському ТВД із зосередженням головних зусиль на Балтійському регіоні. Отже, аналіз застосування ЗС Російської Федерації під час проведення СКШН серії “Захід” є актуальним.

Мета статті. Під час аналізу положень СКШН серії “Захід”, виділити спрямованість заходів оперативної і бойової підготовки ЗС РФ і готовності їх до різного роду можливих масштабних військових операцій проти імовірних противників РФ. 
На основі аналізу СКШН серії “Захід” виділити характерні особливості завдань, принципів та форм і способів застосування видів і родів військ ЗС РФ.

Виклад основного матеріалу. Так, уперше після розпаду СРСР, навчання “Захід1999” було проведено з 21 по 26 червня 1999 року в п'яти військових округах Ленінградському, Московському, ПівнічноКавказькому, Приволзькому, Уральському, які на той час отримали статус оперативностратегічних напрямків, як відповідь РФ на військову операцію США та НАТО “Союзницька сила" проти Союзної Республіки Югославія (мала на меті примушення керівництва Сербії до припинення геноциду албанського населення Косово). Крім того, через демонстрацію готовності до військового протистояння із США та НАТО Росія попереджувала їх про неприпустимість втручання у іiі дії в Чечні (у 1999 році РФ була розпочата друга компанія за відновлення контролю над Чеченською Республікою) $[3,4]$.

Після відносного налагодження відносин між РФ та США і НАТО на початку 2000-х РФ тимчасово призупинила проведення таких СКШН, однак не відмовилась від них. Наступні навчання “Захід-2009” було проведено на фоні чергового ускладнення російськоамериканських та російсько-європейських відносин після нападу РФ на Грузію в серпні 2008 року. Таким чином РФ знову попереджувала США та НАТО про неприпустимість втручання у іiі дії на пострадянському просторі. Завдання навчань - безпосередня підготовка ЗС РФ і Білорусі до забезпечення стратегічної стабільності в Східноєвропейському регіоні $[3,5]$.

Такий самий показовий характер мало СКШН “Захід-2013”, під час якого було відпрацьовано значний комплекс дій 3 підготовки РФ до збройної агресії проти України та стримування США і НАТО. Крім того було проведено оцінювання оперативної сумісності збройних сил РФ та Білорусі $[3,6]$.

Активний етап СКШН “Захід-2017” був проведений 14-20 вересня 2017 року на білоруській та російській територіях під керівництвом начальників генеральних штабів РФ і Республіки Білорусь (РБ). До того ж, на відміну від минулих років, коли навчання серії “Захід” мали відверто демонстративний характер, у 2017 році керівництво РФ суттєво зменшило реальні масштаби СКШН та приховало його дійсний характер. Причиною цього стали критично негативні наслідки санкцій США та ЄС проти РФ та загроза їх подальшого посилення у відповідь на черговий прояв “Москвою” агресивності iі зовнішнього курсу.

Так, на офіційному рівні СКШН “Захід2017” була названа лише частина широкого комплексу навчань ЗС РФ, які проводились на єдиному оперативному фоні у період 3 середини серпня до середини жовтня 2017 року. До того ж був зроблений наголос на суто "оборонному" характері СКШН, його “контртерористичній” спрямованості та “ненаправленості проти будь-яких інших країн”.

Сценарій СКШН включав такі основні складові [3, 7]:

застосування Регіонального

угруповання військ РФ і Білорусі для придушення масових соціальних заворушень (фактично “кольорової” революції) на білоруській території, які були організовані західними країнами для зміни влади в країні;

проведення збройними силами РФ i Білорусі наступальної операції для встановлення контролю над країнами Балтії. Зважаючи на досвід “гібридних" війн РФ проти України та інших пострадянських країн демократичного та європейського вибору, умови для нападу на Литву, Латвію та Естонію можуть бути створені за допомогою провокування внутрішніх конфліктів на їх території з подальшим втручанням у них під приводом захисту російськомовного населення;

забезпечення оборони території РФ на всіх інших напрямках силами Південного, Центрального та Східного військових округів, а також інших видів та родів військ, дислокованих на їх території;

нанесення ядерних ударів по США та інших країнах НАТО у разі стратегічного програшу РФ.

СКШН “Захід-2017” проводилось за декількома етапами $[3,7]$.

Перший (підготовчий) етап розпочинався 3 попередньої підготовки - 3 лютого по серпень 2017 року, під час якої 
проводилося планування навчання та здійснювались окремі заходи $з$ відпрацювання його основних питань.

Так, фактичною “репетицією” СКШН “Захід-2017” стала комплексна перевірка 3С РФ за зимовий період навчання в березніквітні 2017 року. У межах перевірки була проведена низка навчань і тренувань військ Регіонального угруповання збройних сил РФ і Білорусі, а також Західного військового округу (ВО) ЗС РФ. До того ж відпрацьовувались елементи організації та проведення наступальної операції на Північно-Західному (Балтійському) напрямку.

Крім того, у липні 2017 року було проведено командно-штабне навчання (КШН) 3 управління авіацією та військами ППО ЗС РФ на Західному стратегічному напрямку iз залученням оперативних груп від Збройних сил Республіки Білорусь.

Безпосередня підготовка - 3 середини серпня 2017 року до початку навчання, під час якої здійснювались $[3,7]$ :

перевірка готовності федеральних органів виконавчої влади та підприємств оборонно-промислового комплексу до дій в умовах воєнного часу;

проведення мобілізації. Загалом із запасу було призвано майже 100 тис. резервістів. 3 огляду на це Міністерством оборони РФ був оприлюднений законопроєкт щодо внесення змін до федеральних законів "Про оборону” та "Про військову повинність і військову службу”. Законопроєкт був підготовлений як акт воєнного часу. Згідно 3 документом президент РФ отримував право надавати наказ про призов громадян на військову службу по мобілізації та у воєнний час виходячи 3 фактичних потреб збройних сил та інших силових структур (з урахуванням поповнення втрат та особового складу нових 3’ єднань і частин);

налагодження взаємодії між штабами різних рівнів збройних сил РФ і Білорусі для організації та проведення СКШН. Зокрема, такі заходи включали створення спільних оперативних груп, встановлення каналів зв'язку, а також узгодження дій учасників навчання;

розгортання системи логістичного забезпечення навчання та організація транспортних перевезень.

У межах виконання наведених завдань напередодні СКШН було проведено низку окремих і спільних спеціальних навчань 3 органами військового управління, 3'єднаннями та військовими частинами i організаціями тилового, технічного (матеріально-технічного) забезпечення збройних сил обох країн.

Навчання мали на меті удосконалення оперативної сумісності органів військового управління під час переведення військ у вищі ступені бойової готовності, а також відпрацювання питань матеріальнотехнічного, інженерного, моральнопсихологічного, медичного, топографічного та гідрометеорологічного забезпечення військ.

Крім того, відпрацьовувались питання організації зв'язку, радіаційного, хімічного та біологічного захисту, розгортання дорожньотранспортної інфраструктури, технічного прикриття об'єктів і визначених ділянок автошляхів, евакуації, ремонту та відновлення несправної техніки та озброєння, розгортання польового магістрального трубопроводу, а також ділянок масової заправки техніки.

Другий етап СКШН “Захід-2017” розпочинався 3 розгортання міжвидового Регіонального угруповання збройних сил РФ i Білорусі на білоруській та російській територіях.

Перекидання російських військ до району проведення навчання на території Білорусі здійснювалось комбінованим шляхом: залізничним, повітряним та автомобільним транспортом, зокрема своїм ходом.

Крім передислокації військ під час СКШН особлива увага приділялась розгортанню системи управління воєнного часу Західного та частково Південного ВО 3С РФ та ЗС Республіки Білорусь, зокрема польові рухомі командні пункти армій та підпорядкованих їм з' єднань і частин. До того ж застосовувалась Єдина система управління тактичної ланки, яка використовується російськими окупаційними військами на сході України.

Під час третього етапу СКШН “Захід2017” проводились антитерористична, оборонна та наступальна операцій.

Згідно 3 офіційною версією навчання, яка була оголошена командуванням ЗС РФ, на першій фазі цього етапу навчання 14-16 вересня 2017 року на полігонах “Борисовский” та “Осиповичский” силами Регіонального угруповання ЗС РФ і Білорусі вирішувались завдання: знищення ворожих 
диверсійних груп, ізоляції районів дій незаконних збройних формувань, відбиття повітряного нападу противника, а також нанесення повітряних i ракетноартилерійських ударів по силах і об'єктах його інфраструктури $[3,7]$.

Такі ж завдання у складі Регіонального угруповання військ (сил) на Західному напрямку виконували інші підрозділи Західного ВО, Балтійського флоту, повітрянокосмічних сил (ПКС), повітрянодесантних військ (ПДВ) та військ спеціального призначення на полігонах “Лужский”, “Струги Красные” у Ленінградській області та “Правдинский” у Калінінградській області РФ $[3,7]$.

Крім того, у Ленінградській області було проведено окреме навчання 3 відпрацювання питань прикриття Центрального промислового району РФ від повітряного нападу противника.

На тлі вирішення зазначених завдань у штабах відповідних рівнів здійснювались заходи 3 планування стратегічної операції (при офіційно заявленому проведенні “антитерористичної” операції) у районах відповідальності, а також нарощування Регіонального угруповання військ (сил) завдяки прибуттю до Білорусі російських військ.

На другій фазі третього етапу навчання з 17 по 20 вересня 2017 року на полігонах у РФ і Білорусі та в акваторії Балтійського моря військами (силами) Регіонального угруповання ЗС РФ та РБ і російських збройних сил був проведений розіграш практичних дій з ведення маневреної оборони, переходу до наступальних дій та завершення розгрому противника. Основні зі згаданих заходів відпрацьовувались 18 вересня на полігоні “Лужский” та 20 вересня на полігоні “Борисовский” [3, 7].

Згідно $з$ легендою, групи терористів, які прорвалися до Білорусі, об'єдналися в декілька загонів та розпочали підготовку до проведення терактів і диверсій.

У такій ситуації Регіональному угрупованню військ РФ і Білорусі було поставлене завдання щодо знищення бойовиків, а також відновлення територіальної цілісності Республіки Білорусь та наведення конституційного ладу на iі території.
У межах виконання цього завдання були проведені операції з блокування спроб загонів терористів просунутися в глибину території Білорусі, а також оточення та ліквідації їх формувань. Найбільш масштабний характер мали заходи бригадного рівня на полігоні “Борисовский” за участю підрозділів 6 отбр та ПДВ ЗС РФ, а також мотострілецьких, танкових, зенітних та спеціальних підрозділів ЗС Білорусі.

На інших полігонах навчальні питання відпрацьовувались на рівні батальйонних тактичних груп (БТГ).

Як на першій, так і на другій фазі навчань, завдання вогневого ураження умовного противника вирішувалися силами $[3,7]$ :

ракетно-артилерійських підрозділів Західного ВО. Здійснювались умовні пуски оперативно-тактичних ракет "Искандер-М" і тактичних ракет “Точка-У”, а також проводилися бойові стрільби з буксируваних гаубиць “Мста-Б” і реактивних систем залпового вогню "Град". Стрільба велася по повнорозмірних мішенях, які імітували бойову техніку та фортифікаційні споруди умовного противника, прямою та напівпрямою наводкою на різних дальностях. До того ж застосовувались розвідувально-вогневі контури у складі БпЛА, засобів артилерійської розвідки “Аистенок”, а також комплексу розвідки, управління та зв'язку “Стрелец”;

фронтових бомбардувальників Су-34 та літаків дальньої (стратегічної) авіації Ту22M3. Під час розіграшу епізоду фронтова авіація Західного ВО застосовувала авіаційні бомби вагою 250 кг із використанням новітньої обчислювальної підсистеми "Гефест", яка суттєво підвищує точність бомбометання. Польоти проводилися двома ланками по чотири літаки в кожній. Загалом залучалось понад 10 літаків;

корабельних угруповань Балтійського флоту ВМС РФ. Корабельні ракетні стрільби проводились у складній радіоелектронній обстановці із застосуванням засобів РЕБ. Завдання із забезпечення безпеки виконували понад 10 кораблів та суден забезпечення БФ.

Під час навчань із застосуванням засобів АCУ та зв'язку 6-го покоління (у т. ч. супутникових i тропосферних радіостанцій, цифрових радіорелейних станцій Р-419MП “Андромеда-Д” та уніфікованих радіостанцій 
Р-166-05) відпрацьовувалися питання координації дій Південного та Західного ВО на рівні Міноборони РФ, а також управління військами від об'єднань до з'єднань, частин і підрозділів, включаючи БТГ.

Також на тлі СКШН “Захід-2017” проводились заходи оперативної та бойової підготовки у Стратегічних ядерних силах 3С РФ $[3,7]$.

3 початку i до кінця вересня 2017 в ракетних військах стратегічного призначення (РВСП) проходили комплексні навчання за участю одинадцяти ракетних полків у двадцяти регіонах країни.

Відпрацьовувались питання [3, 7]:

переведення частин РВСП у підвищенні ступені бойової готовності;

виходу рухомих ракетних комплексів "Тополь", “Тополь-М" та "Ярс" на маршрути бойового патрулювання у денний та нічний час;

освоєння нових маршрутів бойового патрулювання та бойових позицій;

обладнання польових складів інженерних боєприпасів, ракетноартилерійського озброєння, палива та мастильних матеріалів, продовольства та спорядження;

протидії ударам високоточної зброї та диверсійним групам противника;

радіаційного та хімічного захисту.

Основними цілями навчань стало оцінювання реального стану справ та рівня бойової готовності ракетних частин і з'єднань, а також якості роботи керівного складу щодо організації виконання поставлених завдань на 2017 навчальний рік. Комісія командування РВСП проінспектувала стан бойової підготовки та перевірила злагодженість дій військовослужбовців під час виконання завдань.

У цей період також було здійснено три навчально-бойові пуски міжконтинентальних балістичних ракет (МБР), зокрема [3, 7]:

12 вересня - випробувальний пуск 3 космодрому Плесецьк (Архангельська обл.) твердопаливної МБР "Ярс" шахтного базування, оснащений бойовою частиною, що розділяється;

20 вересня - випробувальний пуск 3 космодрому Плесецьк МБР “Ярс" мобільного базування;
26 вересня - випробувальний пуск МБР РС-12М "Тополь-М".

Водночас шість літаків дальньої (стратегічної) авіації ПКС ЗС РФ Ту-95МС та Ту-22М3 здійснювали політ у повітряному просторі над Баренцовим, Балтійським i Норвезьким морями у супроводі, на окремих ділянках, винищувачів F-16 ВПС Бельгіï, F-18 ВПС Фінляндіï, F-15 та F-16 ВПС США та JAS 39 ВПС Швеції.

Під час СКШН, як стратегічна складова ВМС ЗС РФ, ракетний підводний крейсер стратегічного призначення “Дмитрий Донской” Північного флоту РФ здійснив електронний пуск МБР морського базування.

Паралельно із СКШН “Захід-2017” на початку вересня, а саме 35 по 10 вересня у Південному військовому окрузі (ПдВО) проходили КШН усіх трьох загальновійськових армій округу та окремих видів військ.

Особливістю КШН стало його проведення на тлі навчань НАТО “Agile Spirit 2017” на території Грузії.

Брало участь у КШН близько 2 тис. військовослужбовців та 200 од. військової техніки. Згідно 3 офіційним повідомленням командування ПдВО, сценарій навчання передбачав відпрацювання питань прикриття державного кордону РФ у районах перевалів через Великий Кавказький хребет (на російсько-грузинському кордоні), а також виявлення та ліквідації розвідувальнодиверсійних груп противника у гірській та рівнинній місцевостях. До того ж ураховувався досвід війн у Чечні та російсько-грузинського конфлікту в 2008 році $[3,7]$.

Крім того, вирішувались завдання посилення угруповання збройних формувань самопроголошених республік на Кавказі та російських військ на окупованих територіях України.

У межах навчань ПдВО було відпрацьовано також комплекс заходів оперативної та бойової підготовки угруповання російських військ на території окупованого Криму.

15 вересня 2017 року на полігоні Опук у районі Феодосії було проведено батальйонне тактичне навчання за участю мотострілецьких, танкових та артилерійських підрозділів зі складу 810-ї окремої бригади 
морської піхоти та 126-ї бригади берегової оборони 22-го корпусу берегових військ Чорноморського флоту РФ. Відпрацьовувались дії військ в умовах застосування противником хімічної зброї та засобів РЕБ. Під час навчання розвідувальні підрозділи застосовували комплекси БПЛА “Орлан-10”, які передавали інформацію щодо місцезнаходження умовного противника на пункти управління мінометних батарей “Сани” та гаубичних батарей "Мста-Б”.

Загалом під час КШН було проведено понад 100 тактичних навчань і стрільб, а 3 полігону на території Криму було здійснено пуск крилатої ракети.

У Західному ВО 12 вересня під час навчань 6-ї армії військово-повітряних сил та протиповітряної оборони (ВПС та ППО) ПКС ЗС РФ відпрацювались завдання щодо завоювання переваги у повітрі, над сушею та над морем, зокрема в районах Ленінградської, Курської, Тверської, Калінінградської областей. Загалом залучались понад 100 літаків i вертольотів, включаючи винищувачі МІГ-29СМТ, МІГ-31БМ, Су-27 та Су-30СМ. Під час навчання проводились навчальні повітряні бої та здійснювалися пуски керованих ракет.

З 12 по 29 вересня 2017 року у Центральному ВО здійснювався комплекс заходів оперативної та бойової підготовки. Так, уперше під час навчань військ РЕБ відпрацьовувались питання виявлення та подавлення систем зв'язку та управління стратегічного угруповання військ умовного противника, яке перебувало на дальності до 4 тис. км від Уралу в районах Атлантики та Індійського океану (баз, корабельних груп та авіації ЗС США). Крім того, за допомогою комплексу управління частинами (підрозділами), засобами РЕБ РФ вирішувались завдання захисту критично важливих об'єктів від масованого ракетноавіаційного удару умовного противника, а також дезорганізації управління диверсійнорозвідувальних груп, зокрема блокування їх засобів мобільного зв'язку.

25 вересня під час навчань ракетних військ i артилерії Центрального ВО на полігоні під Челябінськом за участю понад 1 тис. військовослужбовців та 150 од. бойової i спеціальної техніки відпрацьовувались питання ураження цілей на дальність до 18 км iз застосуванням розвідувальних комплексів “Стрелец” та БпЛА “Орлан-10”. Усього було виконано близько 40 вогневих завдань.

У цей період у Східному ВО було проведено оцінювання здатності органів військового управління та з'єднань округу до виконання завдань за призначенням.

Комплексні заходи оперативної та бойової підготовки під час СКШН “Захід2017” також здійснювались на Чорноморському і Північному флотах.

6 вересня 2017 року на Чорноморському флоті під час проведення КШН відпрацьовувались питання управління корабельними групами Кримської та Новоросійської військово-морських баз Чорноморського флоту РФ.

На Північному флоті (ПФ) у навчанні брали участь бойові кораблі, які здійснили перехід до архіпелагу Новосибірських островів, а також підрозділи тактичної групи флоту 3 місцем постійного базування на острові Котельний.

315 по 22 вересня проводились навчання різнорідних сил флоту в Баренцовому морі за участю понад 20 бойових кораблів та 10 атомних і дизельних підводних човнів. Водночас відпрацьовувались питання відбиття масованої повітряної атаки (було збито 6 крилатих ракет), а також нанесення артилерійських і ракетних ударів по кораблях i берегових цілях противника.

У період проведення СКШН “Захід2017” здійснювались військові навчання на територіях самопроголошених республік колишнього СРСР.

20 вересня 2017 року мотострілецький батальйон зі складу Оперативної групи російських військ у Придністров'ї та артилерійського підрозділу збройних формувань самопроголошеної Придністровської Молдавської Республіки відпрацьовували питання оборонних i наступальних дій військ за підтримки артилерії.

В Абхазії 25 вересня 2017 року за участю підрозділів 7-ї військової бази Південного ВО ЗС РФ відпрацьовувались дії БТГ з бойовими стрільбами.

Крім того, було проведено серію військових навчань ЗС РФ та іiї партнерів, у тому числі:

у серпні-вересні проводилось спільне навчання ВМС РФ та Китаю "Морська взаємодія-2017”. Проводилось у два етапи у 
Балтійському та Японському морях. Відпрацьовувались питання спільних дій під час проведення рятувальних операцій $[3,8]$;

28 серпня - середина вересня - спільне навчання ЗС РФ та Монголії “Селенга-2017”. Проводилось на полігоні “Зуунбаян” у пустелі Гобі на монгольській території. Відпрацьовувались питання ліквідації незаконних збройних формувань у складних природних умовах $[3,9]$.

6-17 вересня - спільне навчання підрозділів повітряно-десантних військ РФ та парашутно-десантних військ Єгипту “Захисник дружби-2017”. Навчання проводилось на полігоні “Раевское" у Краснодарському краї РФ. Відпрацьовувались питання захоплення та угримання перевалів 3 висадкою повітряних десантів із літаків Іл-76 [3, 10];

26 вересня - 4 жовтня - спільне навчання гірських підрозділів ЗС РФ та Пакистану “Дружба-2017”. Проводилось на території Карачаєво-Черкесії у високогірному районі Кавказького хребта на висоті 2,3 тис. метрів над рівнем моря. Відпрацьовувались питання взаємодії під час виконання навчально-бойових завдань у гірських умовах, зокрема знищення незаконних збройних формувань [3, 11].

Висновки. Головною метою СКШН “Захід-2017” була демонстрація сили перед США i НАТО у Європі та відпрацювання сценарію підготовки до широкомасштабної війни з ними на Європейському ТВД на основі нових доктринальних документів. Вирішувались завдання організації та проведення антитерористичної, наступальних і оборонних операцій.

Аналіз характеру та спрямованості заходів оперативної та бойової підготовки ЗС РФ підтверджує, що СКШН серії “Захід” були підсумковим етапом бойової підготовки Регіонального угруповання вій ськ збройних сил РФ і Білорусі. приділена:

Під час підготовчого етапу значна увага готовності федеральних органів виконавчої влади та підприємств обороннопромислового комплексу до дій в умовах воєнного часу;

організації забезпечення оперативного розгортання. Проведені спеціальні навчання 3 органами військового управління, з'єднаннями та військовими частинами i організаціями тилового, технічного, інженерного, моральнопсихологічного, медичного, топографічного та гідрометеорологічного забезпечення військ, під час яких відпрацьовувались питання організації зв'язку, радіаційного, хімічного та біологічного захисту, розгортання дорожньо-транспортної інфраструктури, технічного прикриття об'єктів і визначених ділянок автошляхів, евакуації, ремонту та відновлення несправної техніки та озброєння, розгортання польового магістрального трубопроводу, а також ділянок масової заправки техніки.

Висування, під час розгортання міжвидового угруповання збройних сил на білоруській та російській територіях, здійснювалось комбінованим шляхом 3 використанням залізничного, повітряного, автомобільного транспортом та своїм ходом.

Система управління була розгорнута на польових рухомих командних пунктах армій та підпорядкованих їм з'єднань і частин. До того ж застосовувалась Єдина система управління тактичної ланки із застосуванням засобів АСУ та зв'язку 6-го покоління (у т. ч. супутникових і тропосферних радіостанцій, цифрових радіорелейних станцій Р-419МП “Андромеда-Д” та уніфікованих радіостанцій Р-166-05).

Під час третього етапу СКШН міжвидовим угрупованням збройних сил відпрацьовані дії в антитерористичній, оборонній та наступальній операціях.

Під час антитерористичної операції вирішувались завдання: знищення диверсійних груп, ізоляції районів дій незаконних збройних формувань, відбиття повітряного нападу противника, а також нанесення повітряних та ракетно-артилерійських ударів по силах і об'єктах його інфраструктури. Крім того виконано завдання 3 нарощування угруповання військ.

Оточення та ліквідації загонів терористів здійснювалося батальйонними тактичними групами, а також танковою бригадою у взаємодії з десантними та спеціальними підрозділами.

Оборонна та наступальна операції відпрацьовані під час КШН трьох загальновійськових армій ПдВО.

Вогневе ураження умовного противника під час навчань вирішувалися силами:

ракетно-артилерійських підрозділів;

фронтових бомбардувальників Су-34 та літаків дальньої (стратегічної) авіації Ту-22М3; корабельних угруповань флоту ВМС РФ.

Для виконання завдання завоювання переваги у повітрі, над сушею та над морем залучались понад 100 літаків i вертольотів, включаючи винищувачі МІГ-29СМТ, МІГ31БM, Су-27 та Су-30СM.

Уперше війська РЕБ відпрацьовували питання виявлення та подавлення систем зв'язку та управління стратегічного угруповання військ умовного противника, яке перебувало на дальності до 4 тис. км. 
Продемонстрована готовність застосування Стратегічних ядерних сил ЗС РФ. Здійснені пуски та удари 3 рухомих ракетних комплексів, ракетних комплексів шахтного базування, літаків дальньої (стратегічної) авіації та ракетного підводного крейсера стратегічного призначення.

Проведені заходи оперативної та бойової підготовки угруповання російських військ на території окупованого Криму, самопроголошеної Придністровської Молдавської Республіки та Абхазії.

СКШН “Захід-2017” показали здатність і готовність ЗС РФ вирішувати завдання національних інтересів і інтересів партнерів на Західному напрямку. Проте 3 порівняння сучасних військових потенціалів РФ та США і НАТО, на сьогодні командуванням ЗС РФ поки розглядаються обмежені варіанти конфліктів і війн із Заходом у межах окремих регіонів.

Матеріали статті будуть корисні під час розроблення КШВГ, КШН, тактичних та тактико-спеціальних навчань. Надалі $\epsilon$ необхідність провести аналіз бойового застосування ЗС РФ за досвідом СКШН серії “Кавказ”, “Центр”, “Схід” як головних елементів воєнно-політичної діяльності РФ у воєннополітичній сфері та підсумковими етапами бойової підготовки іiі збройних сил - одного 3 основних інструментів РФ 3 реалізації иї зовнішньої, а за певних обставин, і внутрішньої політики.

\section{СПИСОК ВИКОРИСТАНОЇ ЛІТЕРАТУРИ}

1. Воєнна доктрина РФ. 2014. URL: https://militaryarms.ru (дата звернення: 23.04.2020).

2. Стратегія національної безпеки РФ. 2015. URL: https://rg.ru>nac-bezopasnost-sate-doc (дата звернення: 23.04.2020).

3. Завдання бойового застосування Збройних сил РФ на основних стратегічних (операційних) напрямках. URL: https// www.bintel.com.ua (дата звернення: 15.05.2020).

4. ЗАПАД-99. URL: https://www.pravda.ru (дата звернення: 15.05.2020).

5. Оперативно-стратегические учения “Запад-2009”. URL: https://kremlin.ru (дата звернення: 15.05.2020).

6. Стратегические военные учения “Запад-2013”. URL: https://kremlin.ru (дата звернення: 15.05.2020).

7. Учения “Запад-2013”: проверка нервной системы российской армии. URL: https://tass.ru (дата звернення: 22.05.2020).

8. Российско-китайские учения "Морское взаимодействие". URL: http:// tass.ru

9. Российско-монгольские учения "Селенга" URL: http://tass.ru, http://syria.mil.ru (дата звернення: 22.05.2020).

10. “Захисник дружби-2017”. URL: http://eadaily.com, http://function.mil.ru/ (дата звернення: 22.05.2020).

11. Пакистан и Россия начали совместные контртеррористические учения “Дружба-2017”. URL: http://www.golos-ameriki.ru (дата звернення: 22.05.2020).

Стаття надійшла до редакційної колегії 25.12.2020

\section{Analysis of the combat use of the armed forces of the Russian Federation during the strategic command and staff exercises of the "West" series}

\section{Annotation}

Carrying out large-scale military operations is one of the main tools for implementing Russia's foreign policy. During the strategic command and staff exercises (SCSE), the forms and methods of using the types and branches of the RF Armed Forces in terms of basic tasks and new doctrinal documents were tested, which requires analysis and study.

The purpose of the article is to analyze the provisions of the SCSE "West" series, to highlight the direction of operational and combat training of the RF armed forces and their readiness for various possible large-scale military operations against possible enemies of the Russian Federation. Based on the analysis of the SCSE "West" series to identify the characteristics of the tasks, principles and forms and methods of application of types and branches of the armed forces of the Russian Federation.

The main goal of the SCSE "West-2017" was to demonstrate strength to the United States and NATO in Europe and to work out a scenario of preparation for a large-scale war with them at the European battlefield on the basis of new doctrinal documents. The tasks of organizing and conducting anti-terrorist, offensive and defense operations were solved.

The SCSE "West-2017" showed the ability and readiness of the RF armed forces to address national interests and the interests of partners in the western direction. However, comparing the current military capabilities of Russia and the United States and NATO, the Russian armed forces command is currently considering limited options for conflicts and wars with the West within individual regions.

The materials of the article will be useful during the development of command and staff war games, command and staff training, tactical and tactical-special exercises. In the future, there is a need to analyze the combat use of the Russian armed forces in the experience of strategic command and staff trainings of the series "Caucasus", "Center", "East", as the main elements of military and political activities in the military-political sphere and the final stages of combat training - one of the main tools of the Russian Federation for the implementation of its foreign and, under certain circumstances, domestic policy.

Key words: military exercises; military operations; operational and combat training; the Cold War; forecast; security. 